\title{
Comparative Characteristics of Informal Sector Workers in Kuta Beach Versus Sanur Beach
}

\author{
Nilakusmawati DPE and Susilawati M \\ Mathematics Department, \\ Faculty of mathematics and Natural Science, Udayana University \\ Badung, Indonesia \\ nilakusmawati@unud.ac.id, mdsusilawati@unud.ac.id
}

\begin{abstract}
This study aims to compare the socio-economic characteristics of informal sector workers who run their business in the location of Kuta Beach, Badung-Bali versus Sanur Beach, Denpasar-Bali. Data were obtained from primary sources using questionnaires and sampling was done by purposive sampling. Informal sector workers who are respondents include street vendors, hawkers, masseuseers, photo artisans, souvenir vendors, and other personal services such as canoe rental, umbrellas rental, and others. The variable characteristics of the respondents were 15 variables of socioeconomics. Descriptive analysis is used to obtain an overview of socioeconomic characteristics of informal sector workers in the two sites studied. The result showed the average age of informal sector workers in Kuta beach is 50 years and Sanur 44 years. Working hours per day are not much different between two sites. The average income of respondents in Kuta Beach is lower than the average income of workers in Sanur. Workers in Kuta beach have been running relatively longer businesses compared to workers in Sanur beach. The relatively similar characteristics of workers between the two sites are sexes dominated by female workers, with marital status, mostly migrants with a length of stay of more than 5 years, with the status of homes occupied mostly by rent. Most workers in both sites are workers with self-employment status with workers of unpaid families. The findings of the study indicate a difference in the educational level of workers for the two comparable sites. There are also differences in the nature of merchandise services.
\end{abstract}

Keywords: Demographic characteristics, informal sector, informal sector workers, job characteristics, study comparative

\section{INTRODUCTION}

Most of the working population in the province of Balistill rely on informal activities. Statistics of Bali Province [1] showed that in August 2012 1,065.05 thousand people $(46.95 \%)$ worked in formal activities and 1,203.66 thousand people $(53.05 \%)$ worked on informal activities. According to Leibo [2], informal sector workers in the population census data are referred to as self-employed unemployed workers, self-employed with casual workers or unpaid family and family workers.

Tinker [3]) explains that the existence of substantial literature about the informal sector, there is still no concise and universally agreed definition of this sector. Studies indicate that there are at least as many ways of defining the informal sector as there are countries where it has been studied. Furthermore, according to Pick et al [4], the boundaries of the informal sector vary greatly depending on the geographical and historical context within which it is being discussed and according to theoretical and methodological approaches adopted in a particular study.
The description of the informal sector in Indonesia by Hidayat (in Effendi [5]) suggests the following characteristics: Business activities are not well organized, since the business units that arise do not use the facilities or institutions available in the formal sector; Generally, the business unit does not have a business license; Pattern of irregular business activity both in terms of location and working hours; In general, the government's policy to help the economically weak group does not reach this sector; Business units are easily in and out of one sub-sector to another sub-sector; The technology used is traditional; Capital and business turnover is relatively small, so the scale of operation is also relatively small; To run a business is not required formal education because the necessary education is obtained from experience while working; In general, businesses including groups who work on their own business and when working on workers come from families; Sources of business capital funds generally come from personal savings or from unofficial financial institutions; Production or service is mainly consumed by city or village who are low income but sometimes also middle-income. 
Based on existing concepts and adapted to current conditions and the considerations of development progress that have been achieved, those categorized into the informal sector in this study are: (1) The pattern of irregular activities, both in terms of time, capital, and income; (2) The capital, equipment or turnover is usually small and cultivated on a daily basis; (3) Has no linkage with other large businesses; (4) Business location, some are sedentary and some are mobile; (5) Does not require higher education level; (6) It is an individual business activity or a small business unit that employs a small workforce (less than 10) from a family relation, acquaintance, or from the same neighborhood.

Cukier and Wall [6] have researched informal workers in the field of tourism in the two tourist sites in Bali, which focuses on street vendors in Kuta and Sanur. The results of the study show that most workers are unmarried teenagers or young adults with limited formal education but their substantial language skills have been obtained during the work. Most vendors were male. However, there are genderbased differences in products sold. The income level is the main difference between vendors in Bali, the higher income possibilities gained in Kuta compared to Sanur, but at the expense of greater competition.

Based on the study of theory and empirical studies above, this study aims to compare the social and economic characteristics of informal sector workers are operating in the location of tourist attractions Kuta beach, Badung, Bali versus the characteristics of workers who are located in Sanur beach, Denpasar-Bali.

\section{RESEARCH METHOD}

Selection of research location which is coastal tourism where informal workers work, studied two coastal tourist location which have characteristic of different visitor from each other, that is Kuta beach and Sanur. Data were obtained from primary sources using questionnaires. Sampling was done by purposive sampling, the number of sample was determined by 50 respondents for each location. The informal sector workers who are the respondents of the research include street vendors, hawkers, masseuse, photographers, souvenir vendors, and other personal services such as canoe rental, umbrellas, and others.

The variables of characteristic of respondent include: Age, Sex, Marital status, Level of education, Status of migration, House type, Nature of merchandise, Working hours/ day, length of business, bookkeeping of business activity, Business registration status, Merchandise type, How to get merchandise, Physical facilities, income, employment status, participation in empowerment program, business capital access, and presence of social security.
Descriptive analysis is used to obtain an overview of socioeconomic characteristics of informal sector workers in the two sites studied. To further clarify the discussion, the characteristics of informal sector workers in this study are described as demographic characteristics and job characteristics.

\section{RESULTS AND DISCUSSION}

\section{A. Demographic Characteristics}

The result showed that the average age of informal workers for Kuta beach site is 50 years and Sanur with an average of 44 years. There is a wider range of worker age for workers at Kuta than Sanur. Workers age in Kuta, there is a very wide range of age, between the youngest age with the oldest age, which is 20 years and 66 years old, while for workers in Sanur with a range of age 32 years and 58 years. With regard to this age range, Hidayat [7] argues that with the nature of the informal sector easily accessible, this sector is able to accommodate the workforce of all ages. This flexible nature causes the informal sector to often become alternative employment opportunities for workers who can't enter the formal sector. With regard to this sector is able to accommodate old-age workers, it is possible that this sector will be a container for the elderly who are still productive in the future.

The relatively similar characteristics between workers at Sanur and Kuta beach are gender dominated by female workers with marital status. The majority of respondents are female workers (72\% in Kuta and $62 \%$ in Sanur), marital status $(86 \%$ and $100 \%)$. This is in contrast to the findings of Cukier and Wall [6] which investigated the informal tourism employment in the tourist sites of Kuta and Sanur in 1994 it was found that the majority of the vendors in both Sanur and Kuta were teenegers and young adults, single $(90 \%$ in Sanur and $70 \%$ in Sanur) and majority were male (97\% in Sanur and $73 \%$ in Kuta). The results of this study when compared with the Cukier \& Wall [6] indicate a change, where in 1994 workers in the location of Kuta and Sanur mostly cultivated by male with unmarried status, in contrast to the current conditions that are dominated by female and married status. This indicates a shift in the characteristics of age, sex and marital status of informal sector workers during the period 1994 to present.

The findings of the study indicate a difference in the educational level of workers for the two comparable sites. Respondents on Kuta beach were dominated by non-school and elementary (SD) (24\% out of school and $44 \%$ SD), while workers at Sanur beach were dominated by workers with elementary and junior high (SMP) (48\% SD and $24 \%$ SMP). In general, the majority of education levels in both sites are elementary (SD). 
TABLE I

DEMOGRAPHIC CHARACTERISTICS OF INFORMAL SECTOR WORKERS AT Kuta Beach Versus Sanur

\begin{tabular}{llrrrr} 
Variable & Category & Kuta & $\%$ & Sanur & $\%$ \\
& & & & & \\
\hline Age & Average age (year) & 50 & - & 44 & \\
\hline \multirow{2}{*}{ Gender } & 1. Male & 14 & 28.0 & 19 & 38.0 \\
& 2. Female & 36 & 72.0 & 31 & 62.0 \\
\hline \multirow{3}{*}{ Marital } & 1. Unmerried & 4 & 8,0 & - & - \\
status & 2. Married & 43 & 86.0 & 50 & 100.0 \\
& 3. Divorced & 2 & 4,0 & - & - \\
& 4. Widow & 1 & 2.0 & - & - \\
\hline \multirow{4}{*}{ Education } & 1. No school & 12 & 24.0 & 5 & 10.0 \\
& 2. Elementary (SD) & 22 & 44.0 & 24 & 48.0 \\
& 3. Junior High & & & & \\
& $\quad$ (SMP) & 5 & 10.0 & 12 & 24.0 \\
& 4. High (SMA) & 11 & 12.0 & 8 & 16.0 \\
& 5. Collage/ & & & & \\
\hline Migration & university & - & - & 1 & 2.0 \\
status & 1. $<$ 5 years & 15 & 30.0 & 6 & 12.0 \\
\hline & 2. $>$ 5 years & 35 & 70,0 & 44 & 88.0 \\
\hline
\end{tabular}

All respondents in both study sites are migrants with a stay longer than 5 years (70\% in Kuta and $88 \%$ in Sanur) and the rest are recent migrants. In contrast to the occupied house status, the majority of workers in Kuta occupy a house with rented status (54\% rent, 44\% own) while workers in Sanur Beach occupy the majority of houses with self-owned status (64\% own, 36\% rent). This indicates that workers in both sites who are mostly migrants with a stay longer than 5 years, have differences in the occupied house status. Workers at the Sanur site are dominated by respondents with their own home status, while workers at the Kuta are dominated by respondents with home status by renting. All respondents who are migrants with a stay longer than 5 years or who are recent are migrants from the island of Java.

The large percentage of self-employed workers indicates that this type of employment as an informal sector worker has helped to improve the livelihoods of most urban households, particularly for workers in the study sites.

\section{B. Job Characteristics}

Average working hours per day for workers in Kuta Beach is 9 hours per day, with a minimum working hour span of 5 hours and a maximum of 12 hours, while working hours for respondents in the Sanur beach is 7 hours per day, with a minimum span of 2 hours and a maximum of 12 hours. The majority of respondents in both sites studied were self-employed workers ( $82 \%$ in Kuta and $96 \%$ in Sanur). The majority of respondents in Kuta $(32 \%)$ are food/beverage sellers, $14 \%$ are clothing sellers, $16 \%$ are sellers of accessories, and the rest are individual service providers such as water sport services (surfing), manicures, photographers, and massage. As for workers in Sanur 40\% are food vendors, $14 \%$ clothing seller, $12 \%$ accesoris, $8 \%$ handycraft, and the rest are service providers such as massage, manicures, and water sports.

The majority of respondents in Kuta beach get merchandise from suppliers (60\%), while workers in Sanur get from suppliers (42\%) and from production/make by ownself (32\%). Physical facilities used in selling goods/services for respondents in Kuta by using table (42\%) and $28 \%$ with mat. While workers in Sanur using baskets (36\%) and $32 \%$ with a mat.

The average monthly income of the two study sites is not much different $(\operatorname{Rp} 2,688,000$, - in Kuta and $R p$ 2,825,000 in Sanur), but seen from the nominal income of respondents in Kuta location is lower than Sanur. This lower income is likely because when data collection is done it is deserted season of visitors. Kuta Beach with the characteristics of visitors is dominated by foreign tourists, when data collection conducted in September and October is a quiet month of visitors. While for workers in Sanur has a relatively higher income compared to Kuta is likely due to the characteristic of visitors of sanur beach dominated by tourists domestic and visitors of residents around the city of Denpasar, so the number of visits is relatively even throughout the year, allows for this distinction. In contrast to Cukier \& Wall [6] suggests that income levels are the main difference between vendors in Bali, the higher income possibilities obtained in Kuta compared to Sanur, but at the expense of greater competition. Many vendors view their current work as a means of acquiring the skills necessary to gain access to employment in the formal sector. However, it is unclear how many succeeded in this goal.

Informal sector workers in Kuta beach have been running relatively long businesses (average 17 years) compared to workers in Sanur beach that is 13 years old. There is a long span of effort between the minimum and maximum length of business (minimum 5 months and maximum 40 years in Kuta, minimum 3 years and maximum 30 years in Sanur).

TABLE II

Job CHARACTERISTICS OF INFORMAL SECTOR WORKERS IN KUTA BEACH VERSUS SANUR

\begin{tabular}{|c|c|c|c|c|c|}
\hline Variable & Category & Kuta & $\%$ & Sanur & $\%$ \\
\hline $\begin{array}{l}\text { Working } \\
\text { hours/day }\end{array}$ & $\begin{array}{l}\text { Average of working } \\
\text { hours/day }\end{array}$ & \multicolumn{2}{|c|}{9} & \multicolumn{2}{|l|}{7} \\
\hline $\begin{array}{l}\text { Bussines } \\
\text { duration }\end{array}$ & $\begin{array}{l}\text { Average bussines } \\
\text { duration (years) }\end{array}$ & \multicolumn{2}{|c|}{17} & \multicolumn{2}{|l|}{13} \\
\hline $\begin{array}{l}\text { Average } \\
\text { income/month }\end{array}$ & Average of income & \multicolumn{2}{|c|}{$2,688,000$} & \multicolumn{2}{|c|}{$2,825,000$} \\
\hline \multirow{4}{*}{$\begin{array}{l}\text { Employment } \\
\text { status }\end{array}$} & Self-employed & 41 & 82.0 & 48 & 96.0 \\
\hline & $\begin{array}{l}\text { Self-employed with } \\
\text { temporary workers }\end{array}$ & 3 & 6.0 & 1 & 2.0 \\
\hline & $\begin{array}{l}\text { Self-employed with } \\
\text { paid workers }\end{array}$ & 6 & 12.0 & 1 & 2.0 \\
\hline & Employee/worker & 8 & 5.2 & - & - \\
\hline \multirow{4}{*}{$\begin{array}{l}\text { How to get } \\
\text { merchandise }\end{array}$} & $\begin{array}{l}\text { Production / make } \\
\text { by ownself }\end{array}$ & 6 & 12.0 & 16 & 32.0 \\
\hline & From suppliers & 30 & 60.0 & 21 & 42.0 \\
\hline & $\begin{array}{l}\text { From manufacturer / } \\
\text { factory }\end{array}$ & 6 & 12.0 & 2 & 4.0 \\
\hline & Others & 8 & 16.0 & 11 & 22.0 \\
\hline
\end{tabular}




\begin{tabular}{|c|c|c|c|c|c|}
\hline \multirow{9}{*}{$\begin{array}{l}\text { Type of } \\
\text { merchandise/ } \\
\text { services }\end{array}$} & Food/drink & 16 & 32.0 & 20 & 40.0 \\
\hline & Clothing/textiles & 7 & 14.0 & 7 & 14.0 \\
\hline & $\begin{array}{l}\text { jewelry/kites/ } \\
\text { sunglasses /toys }\end{array}$ & 8 & 16.0 & 6 & 12.0 \\
\hline & Manicure & 6 & 12.0 & 1 & 2.0 \\
\hline & Water sport & 4 & 8.0 & 5 & 10.0 \\
\hline & Photographer & 2 & 4.0 & - & - \\
\hline & Rental services & 2 & 4.0 & - & - \\
\hline & Massage & 5 & 10.0 & 7 & 14.0 \\
\hline & Handy craft & - & - & 4 & 8.0 \\
\hline \multirow{6}{*}{$\begin{array}{l}\text { Physical } \\
\text { facilities }\end{array}$} & Cart/pikes & 3 & 6.0 & 18 & 36.0 \\
\hline & Mat/gel/base & 14 & 28.0 & 16 & 32.0 \\
\hline & Table & 21 & 42.0 & 6 & 12.0 \\
\hline & Carts/strollers & 7 & 14.0 & - & - \\
\hline & $\begin{array}{l}\text { semi permanent } \\
\text { shop }\end{array}$ & 5 & 10.0 & - & - \\
\hline & Kiosk & - & - & 10 & 20.0 \\
\hline \multirow{2}{*}{$\begin{array}{l}\text { Had additional } \\
\text { jobs }\end{array}$} & No & 46 & 92.0 & 48 & 96.0 \\
\hline & Yes & 4 & 8.0 & 2 & 4.0 \\
\hline Book keeping & No & 50 & 100.0 & 45 & 90.0 \\
\hline \multirow{3}{*}{$\begin{array}{l}\text { Registration of } \\
\text { business } \\
\text { activities }\end{array}$} & Yes & - & - & 5 & 10.0 \\
\hline & No & 47 & 94.0 & 26 & 52.0 \\
\hline & Yes & 3 & 6.0 & 24 & 48.0 \\
\hline
\end{tabular}

The majority of respondents in both sites said they had no alternative income other than just working as informal sector workers (92\% in Kuta and 96\% in Sanur). The results of this study are in line with Joseph [8] in his study of street vendors in Gaborone, the capital city of Botswana, explaining that street vending appears to be the main source of income to most of the respondents as evidenced by $79.4 \%$ who stated that they do not have any other income generating activity. Cukier \& Wall [6] also found the same thing that the vending was their primary occupation, although a substantial minority (30\% in Sanur and $45 \%$ in Kuta) also had additional jobs.

The majority of respondents in both sites stated not do bookkeeping of their business activities (100\% in Kuta and 90\% in Sanur) and not registering their business activities (94\% in Kuta and 52\% in sanur).

Results of interviews with respondents in Kuta beach obtained information that the obligation to pay the retribution fees of varying magnitude from Rp. 2,500 to 45,000 per day, as well as the policy that informal workers who are native of Kuta are not subject to levy fees. But in this study, all respondents at Kuta site is migrant. Their income is uncertain, this depends on the season of tourist visits both domestic and foreign tourists. Described by the respondents that the highest visitor arrivals in August. One of the respondents explained his daily income from umbrella rental services. Every day, the average rent umbrellas for 1-5 visitors, with umbrella rental fee Rp. 50,000 per hour. The majority of drink sellers in Kuta obtain their merchandise from the same suppliers for resale to consumers. The local government has set a deadline for selling at Kuta beach from 7 am to $7 \mathrm{pm}$.

Unlike the case of workers at Sanur beach, the results of interviews with respondents obtained information that saturday, sunday and holiday is the peak day of visitors. In the normal days people visit in the afternoon for sports activities. Their income depends on the number of visitors. According to business location Onyango et al [9] explains that the locations that street vendors took up are usually influenced by attractiveness, accessibility, number of customers, competitors, allocation by municipalities and the original site where vendor businesses started. Further Ndhlovu [10] explains that, for street vendors accessibility to customers is a key consideration and they strategically located on the streets to avoid formalization costs such as rent, taxes and licenses.

In relation to the empowerment of informal sector workers, the majority of respondents in both sites stated that they never participated in the empowerment program in the form of business skills training organized by the government or non-government (94\% in Kuta and $100 \%$ in Sanur). Similarly, for access to opportunities to obtain business capital, the majority of respondents $(70 \%$ in Kuta and $92 \%$ in Sanur) stated that they did not have access to business capital, the rest had access to business capital from Banks, Cooperative (Koperasi) and Village Credit Institutions (Lembaga Perkreditan Desa/LPD). Of all respondents who did not have access to business capitalization using their own capital source, either from their own savings or family assistance.

The participation of respondents in the protection program, in the form of social security such as health insurance, employment insurance, as well as other social security, the majority of respondents in the two study sites stated that they did not have social security (68\% in Kuta and $72 \%$ in Sanur), the rest stated that they have social security in the form of BPJS Kesehatan, BPJS Ketenagakerjaan, private insurance program, and KIS \& JKBM.

Based on the results of the study it can be noted that informal sector workers in both sites have problems in empowerment, such as the low access of these informal workers in business capitalization. Most of the respondents do not have access in obtaining business capitalization, so that the capitalization is sourced from their own capital. Low access to capital from formal capital sources (Bank, Koperasi, LPD) has an impact on the low ability of workers in this sector to develop and promote their businesses. Another problem is the low participation of informal workers in the empowerment program in the form of education/business skills training which is managed by the government and non- government. This indicates that the informal sector is less touched by the empowerment program. Based on the findings of this research, there is a need for further research to clarify the problems mentioned above.

With regard to the participation of informal sector workers in the social security program, most respondents in both sites did not have or did not participate in social 


\section{REFERENCES}

workers in the social security program indicates that the health and employment security program (BPJS Kesehatan dan BPJS Ketenagakerjaan) which has been running for several years in Indonesia needs to be evaluated for its affordability to reach all levels of society, especially the lower middle class. Based on survey results for both study sites, from 100 respondents obtained only 1 respondent who has social security in the form of employment security (BPJS Ketenagakerjaan). Based on this, more intensive socialization is needed to increase the participation of informal workers in the social security program of employment. Socialization to be more emphasized on the social security program of labor for informal sector workers. In line with Joseph's research findings [8] revealed that only $35.6 \%$ of the respondents were making social and/or health insurance contributions from the income they generate in street vending enterprises. Lack of insurance contributions was attributed on the one hand to pressing needs they were faced with and on the other hand to fluctuating incomes to sustain monthly contributions.

The policy is recommended to be directed towards improving the empowerment of informal workers in the form of support for business capital access and increasing workers participation in social security programs (health and/or employment), so that with the condition of workers who are more empowered will also improve their welfare.

\section{CONCLUSION}

Comparison of characteristics of informal sector workers which are relatively similar in both sites Kuta and Sanur beach include: average working hours per day between 7-9 hours, sex is dominated by female workers, with marital status, mostly migrants with a stay longer than 5 years, with the status of the house occupied mostly by renting. Most workers in both locations are workers with self-employment status with workers from unpaid families.

Differences in the characteristics of informal sector workers in both sites showed a difference in the average age of respondents, average monthly income, business duration, workers at Kuta beach running their bussines relatively longer business compared to workers at Sanur beach. There is a difference in the education level of workers, nature of merchandise services, most of the respondents in Kuta get merchandise from suppliers, while workers in Sanur beach get from supplier and from production / make by ownself.

\section{ACKNOWLEDGMENT}

High appreciation to the Udayana University, which has funded this research through funding DIPA BLU Udayana University, Hibah Unggulan Program Studi (HUPS), the Grant Contract No.3630/UN14.2.8.II/LT/2017.
[1] BPS Provinsi Bali. 2012. "Keadaan Ketenagakerjaan Provinsi Bali Agustus 2012,” Berita Resmi Statistik No.62/11/51/Th. VI, 5 November 2012, Available: http://bali.bps.go.id/brs/naker/brs naker_11_2012.pdf

[2] J. Leibo, Problem Perkotaan dan Konflik Sosial. Yogyakarta: Institut Pengembangan Demokrasi dan Hak Asasi Manusia, 2004.

[3] I. Tinker, Street foods: Urban food and employment in developing countries. Oxford: University Press. 1997

[4] W.M. Pick, M.H. Ross, and Y. Dada, "The reproductive and occupational health of women street vendors in Johannesburg, South Africa," Social Science and Medicine 54, 2002, pp. 193 204

[5] T.N. Effendi, Sumber daya Manusia, Peluang Kerja dan Kemiskinan. Yogyakarta: Tiara Wacana, 1993.

[6] J. Cukier and G. Wall, "Informal tourism employment: vendors in Bali, Indonesia. Reports," Tourism Management 15 (6), 1994, pp. 464-476.

[7] Hidayat, Peranan Sektor Informal dalam Struktur Perekonomian Daerah Yogyakarta, Pusat Penelitian Sumberdaya Manusia dan Lingkungan, Universitas Padjadjaran, Bandung. 1978

[8] M.C. Joseph, "The struggle to belong Dealing with diversity in 21st century urban settings. Beyond modernist planning: Understanding urban street vending in Botswana," Paper presented at the International RC21 conference 2011. Amsterdam, 7-9 July 2011

[9] J. Onyango, W. Olima, \& L. Onyango, "Dynamics of street vending phenomenon in the Kisumu Municipality, Kenya," International Journal of Arts and Commerce, 1(4), 2012, pp.107120.

[10] N.P. Ndhlovu, Street vending in Zambia. A case of Lusaka District. Unpublished masters dissertation, Institute of Social Studies (ISS) The Hague, The Netherlands, 2011 